This item was submitted to Loughborough's Research Repository by the author.

Items in Figshare are protected by copyright, with all rights reserved, unless otherwise indicated.

\title{
Facilitating the operational readiness of the NHS for the in-house manufacture and delivery of autologous cell therapy [210]
}

\section{PLEASE CITE THE PUBLISHED VERSION}

https://doi.org/10.1016/j.jcyt.2017.02.219

\section{PUBLISHER}

(C) Elsevier

\section{VERSION}

AM (Accepted Manuscript)

\section{PUBLISHER STATEMENT}

This work is made available according to the conditions of the Creative Commons Attribution-NonCommercialNoDerivatives 4.0 International (CC BY-NC-ND 4.0) licence. Full details of this licence are available at: https://creativecommons.org/licenses/by-nc-nd/4.0/

\section{LICENCE}

CC BY-NC-ND 4.0

\section{REPOSITORY RECORD}

Ziya, S., Nick Medcalf, Alicia J. El Haj, and K.T. Wright. 2019. "Facilitating the Operational Readiness of the NHS for the In-house Manufacture and Delivery of Autologous Cell Therapy [210]". figshare. https://hdl.handle.net/2134/26066. 


\title{
FACILITATING THE OPERATIONAL READINESS OF THE NHS FOR THE IN-HOUSE MANUFACTURE AND DELIVERY OF AUTOLOGOUS CELL THERAPY
}

\author{
S. Ziya ${ }^{1,2}$, N. Medcalf ${ }^{3}$, A. El Haj ${ }^{1}$, K.T.Wright ${ }^{1,2}$ \\ ${ }^{1}$ Institute for Science \& Technology in Medicine, Keele University, Stoke-on- \\ Trent, Staffordshire, United Kingdom, ${ }^{2}$ Robert Jones and Agnes Hunt \\ Orthopaedic Hospital, Oswestry, United Kingdom, ${ }^{3}$ Centre for Biological \\ Engineering, Loughborough University, Loughborough, Leicestershire, \\ United Kingdom
}

Introduction: Cell-based therapies (CBTs) have been shown to confer regenerative capacity in various pathologies. The production of such treatments requires a range of business models. These business models either align with or disrupt the current clinical pathway and therefore it is imperative to understand the impact at the clinical interface and to design manufacture and supply networks in a way that makes adoption as simple as possible.

The present study explores the delivery of cell therapy within several NHS Trust hospitals. CBTs are manufactured under a controlled GMP background, requiring specialist equipment and expertise. This often presents unexpected costs and operational procedures that are unfamiliar to the typical clinical environment.

Methods: This project takes a focus on the flow of information and activities from 'needle-to-needle' for a culture-expanded autologous chondrocyte implantation $(\mathrm{ACl})$ product in a Phase-II clinical trial at a local NHS Trust. A framework has been identified based on conceptual modelling under the IDEFO standard to understand fundamental unit operations. Activity-based costing has been applied to value-adding activities to assess direct and indirect costs of manufacture. A sensitivity analysis has explored how manufacturing parameters, facility overheads and the operational model has impacted upon the cost drivers. Comparison of CBT manufacture at further NHS sites has been explored to understand current practices and the feasibility of change to allow for increased capacity within the constraints of existing infrastructure. Semi-structured interviews have been undertaken with key players through the innovation, adoption and implementation process. Consensus statements have been developed through a two-round Delphi method in order to provide guidance for prospective CBT manufacturers and the NHS.

Results: This mixed methods approach explores and validates perspectives on CBTs within the hospital environment. Clinicans, pharmacists, production and quality scientists have been surveyed from several NHS hospitals across England. It is clear from these discussions that several characteristics of the supply chain are unique to CBTs, including their effect on logistics, distribution, reimbursement and the supply route to the point-of-care.

Conclusion: This study will support a body of research to understand and develop a framework for the clinically integrated manufacture of CBTs and other such advanced therapies within the NHS. 